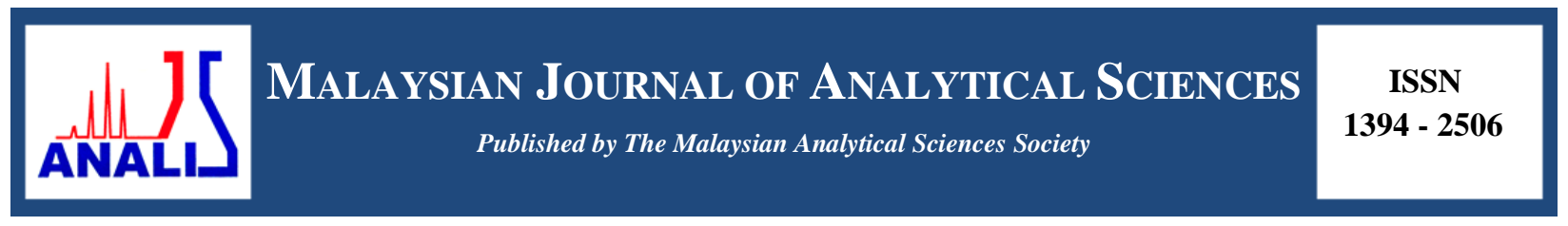

\title{
EFFECT OF LONG TIME OXYGEN EXPOSURE ON POWER GENERATION OF MICROBIAL FUEL CELL WITH ENRICHED MIXED CULTURE
}

\author{
(Kesan Terhadap Penjanaan Kuasa Sel Bahan Api Mikrob dengan Kultur Campuran yang \\ Diperkaya Melalui Pendedahan pada Oksigen untuk Jangka Masa Lama) \\ Mimi Hani Abu Bakar ${ }^{1,2,3 *}$, Neil F Pasco ${ }^{2}$, Ravi Gooneratne ${ }^{3}$, Kim Byung Hong 1,4,5 \\ ${ }^{1}$ Fuel cell Institute, \\ Universiti Kebangsaan Malaysia, 43000 UKM Bangi, Selangor, Malaysia \\ ${ }^{2}$ Lincoln Ventures Ltd, \\ PO Box 133, Lincoln, Christchurch 7640, New Zealand \\ ${ }^{3}$ Lincoln University, PO Box 84, Lincoln, 7647, New Zealand \\ ${ }^{4}$ Korea Institute of Science \& Technology, \\ Seongbuk-ku, Seoul 136-792, Korea \\ ${ }^{5}$ State Key Laboratory of Urban Water Resource \& Environment, \\ Harbin Institute of Technology, Harbin 150090, China \\ *Corresponding author: mimihani@ukm.edu.my
}

Received: 5 February 2016; Accepted: 22 April 2016

\begin{abstract}
In this study, we are interested in the effect of long time exposure of the microbial fuel cells (MFCs) to air on the electrochemical performance. Here, MFCs enriched using an effluent from a MFC operated for about eight months. After 30 days, the condition of these systems was reversed from aerobic to anaerobic and vice versa, and their effects were observed for 11 days. The results show that for anaerobic MFCs, power generation was reduced when the anodes were exposed to dissolved oxygen of 7.5 ppm. The long exposure of anodic biofilm to air led to poor electrochemical performance. The power generation recovered fully when air supply stopped entering the anode compartment with a reduction of internal resistance up to 53\%. The study was able to show that mixed facultative microorganism able to strive through the aerobic condition for about a month at $7.5 \mathrm{ppm}$ oxygen or less. The anaerobic condition was able to turn these microbes into exoelectrogen, producing considerable power in relative to their aerobic state.
\end{abstract}

Keywords: microbial fuel cell, aerobic, oxygen exposure, wastewater

\begin{abstract}
Abstrak
Dalam kajian ini, kami berminat untuk mengesan prestasi elektrokimia sel bahan api mikrob (MFC) terhadap pendedahan jangka masa panjang kepada udara. Di sini, MFC diperkaya menggunakan efluen daripada MFC yang telah beroperasi selama kira - kira lapan bulan. Selepas 30 hari, keadaan sistem ini telah diterbalikkan dari aerobik untuk anaerobik dan sebaliknya, dan kesannya diperhatikan selama 11 hari. Keputusan menunjukkan bahawa untuk MFC anaerobik, penjanaan kuasa telah berkurangan apabila anod terkena oksigen terlarut $7.5 \mathrm{ppm}$. Pendedahan jangka masa panjang biofilem anod kepada udara membawa kepada prestasi elektrokimia yang rendah. Penjanaan kuasa pulih sepenuhnya apabila bekalan udara berhenti memasuki ruangan anod dengan pengurangan rintangan sehingga $53 \%$. Kajian ini dapat menunjukkan bahawa mikroorganisma fakultatif campuran dapat hidup melalui keadaan aerobik selama sebulan pada 7.5 ppm oksigen atau kurang. Keadaan anaerobik mampu mengubah mikrob ini kepada eksoelektrogen, seterusnya menghasilkan kuasa yang tinggi berbanding dengan apabila berada di dalam keadaan aerobik.
\end{abstract}

Kata kunci: sel bahan api mikrob, aerobik, pendedahan oksigen, air sisa 


\section{Introduction}

A microbial fuel cell (MFC) system is a bioenergy converter that utilizes bacteria to generate electricity through bacterial metabolic pathway [1]. These bacteria are known as exoelectrogens and could transfer electrons to anode electrode. Oxygen and nitrate are preferred electron acceptor over the anode reducing power generation in their presence in the anolyte. Tests on the impact of oxygen in air on anaerobic MFCs had been done on both single cell culture, such as from the genus Shewanella [2, 3], Escherichia coli (E. coli) [4] and mixed bacterial cultures from anaerobic wastewater treatment streams [5,6]. It was shown that the dissolved oxygen in anolyte reduces the capability of certain bacteria to transfer electrons to external anode. Kim et al. [7] in their research on biosensor, found that Shewanella putrefaciens completely loss its electrochemical activity within three hours of exposure to air, while Biffinger et al. [8] found that Shewanella oneidensis work well as exoelectrogen in the presence of oxygen. Wang et al. [4] discovered that E. coli had about 61- $68 \%$ decreased in capability to reduce external mediator, hexacyanidoferrate (III) $\left[\mathrm{Fe}(\mathrm{CN})_{6}\right]^{3-}$ in anaerobic MFC when oxygen is presence. In the case of mixed culture, Liu et al. [5] found that the diffusion of oxygen to the anolyte from the catholyte would lead to 21- 50\% loss of substrate to aerobic oxidation by bacteria, which translates as the loss of generated electricity through the MFC.

A more detail work was done by Li et al. [3] on the response of Shewanella decolorationis with oxygen within six days of changing the flowing of argon gas and air into the MFCs to create alternate condition of aerobic and anaerobic. They discovered that in contact with oxygen, $S$. decolorationis reduced more NAD to NADH, which in turns increase in charge production. However, the dissolved oxygen (DO) in the anolyte increased aerobic respiration and biomass production that leads to current reduction in MFCs. There are not many studies reported on aerobic effect towards the anodic biofilm of MFCs [9]. Though available findings pointed out the short term adverse effect of oxygen on generation of current by bacteria in MFCs, to our knowledge there are no reports that show long term oxygen exposure on anolyte in MFC.

Therefore, this study aims to analyse the effect of long-duration exposure towards oxygen on the electrochemical performance of enriched multi-cultured bacteria in MFCs. In this work, effluent from an air-cathode MFC operated for about eight months was used as inocula for aerobic and anaerobic MFCs. After 30 days, the conditions of the system were changed by swapping between the nitrogen and air. This turned the aerobic into anaerobic and anaerobic into aerobic and were let to acclimatize in their new condition for 11 days. The electrochemical performance of the MFCs before and after the gas swapping were compared in view of maximum power density $\left(P_{\max }\right)$, current density $\left(I_{\max }\right)$ at $P_{\max }$ and internal resistance $\left(R_{\text {int }}\right)$ accomplished within the systems.

\section{Chemicals}

\section{Materials and Methods}

Chemicals were of analytical grade. Peptone was purchased from Merck (Darmstadt, Germany). Yeast extract was purchased from Scharlau (Barcelona, Spain). Ammonium chloride $\left(\mathrm{NH}_{4} \mathrm{Cl}\right)$ and sodium acetate anhydrous $\left(\mathrm{CH}_{3} . \mathrm{COONa}\right)$ was purchased from AnalaR ${ }^{\circledR}, \mathrm{BDH}$ Laboratory Supplies (Poole, England). Di-sodium hydrogen orthophosphate anhydrous $\left(\mathrm{Na}_{2} \mathrm{HPO}_{4}\right)$ and potassium chloride $(\mathrm{KCl})$ were purchased from Fisher Scientific UK Ltd. (Leicestershire, UK). Sodium dihydrogen orthosphosphate $\left(\mathrm{NaH}_{2} \mathrm{PO}_{4} \cdot \mathrm{H}_{2} \mathrm{O}\right)$ was purchased from LabServTM, Biolab (Aust) Ltd. (Victoria, Australia). All analytical solution was made using distilled water unless otherwise stated.

\section{Inoculum, buffers, reagents and media}

Effluent from an air cathode MFC inoculated with sludge collected from Bromley Wastewater treatment plant and operated about eight months using acetate as the electron donor was used to inoculate air-cathode MFCs used in this study. The basal medium was prepared by dissolving $0.31 \mathrm{~g} / \mathrm{L} \mathrm{NH} \mathrm{Nl}_{4}, 3.12 \mathrm{~g} / \mathrm{L} \mathrm{NaH} \mathrm{NO}_{4} \cdot 2 \mathrm{H}_{2} 0,4.58 \mathrm{~g} / \mathrm{L} \mathrm{Na}_{2} \mathrm{HPO}_{4}$, and $0.13 \mathrm{~g} / \mathrm{L} \mathrm{KCl}$ in phosphate buffer $(50 \mathrm{mM}, \mathrm{pH} 7.0)[10,11]$. The acetate medium was made by dissolving $1 \mathrm{~g} / \mathrm{L}$ $\mathrm{CH}_{3}$ COONa, $1 \mathrm{~g} / \mathrm{L}$ peptone of casein and $2 \mathrm{~g} / \mathrm{L}$ yeast extract in the basal medium [12]. The medium was autoclaved at $121{ }^{\circ} \mathrm{C}$ for $15 \mathrm{~min}$ prior to use. 


\section{MFC air-cathode construction}

The study utilized single chambered air-cathode MFCs as described in Weld \& Singh [13]. The reactor was constructed using three machined polycarbonate pieces with O-rings and steel bolts. The internal volume was 19.2 $\mathrm{mL}$ (Figure 1). The middle polycarbonate had its top equipped with three holes: two big holes of $\varnothing 1.8 \mathrm{~cm}$ and $\varnothing 1.0$ $\mathrm{cm}$ for batch mode feeding and reference electrode respectively and one small hole of $\varnothing 0.4 \mathrm{~cm}$ for gas inlet. The anode chamber was separated from an air cathode by using cation exchange membrane (Ultrex) from BASF Fuel Cell Inc. (Somerset, NJ. USA).

The air-cathode and the anode were $4 \mathrm{~cm} \times 4 \mathrm{~cm}$ of 10\% Pt-carbon cloth (Fuel Cell Earth LLC, Stoneham, MA) covered with a layer of $4 \mathrm{~cm} \times 4 \mathrm{~cm}$ plain carbon cloth (Fuel Cell Earth LLC, Stoneham, MA) and $4 \mathrm{~cm} \times 4 \mathrm{~cm}$ plain carbon cloth respectively. The cathode was fastened to the exterior wall of the Ultrex membrane with a nickel strip, acted as current collector and also used to grip the anode.

\section{Operation}

Here, $2 \%(\mathrm{v} / \mathrm{v})$ of anolyte $\left(\mathrm{OD}_{600}\right.$ of 2.85) from an eight month old MFC was incubated in acetate media for $24 \mathrm{~h}$ at $150 \mathrm{rpm}$ and $24{ }^{\circ} \mathrm{C}$. Each six new MFCs were filled with $0.4 \mathrm{~mL}$ of the incubated culture and topped up with acetate media. Two of the MFCs were bubbled with nitrogen to create anaerobic condition, the other two were bubbled with air to create aerobic condition, while two more were made as control, free from flowing of gas to create natural anaerobic condition. Except for the controlled MFCs, the anodes of gassed MFCs were poised at potential of +200 $\mathrm{mV}$ (vs. $\mathrm{Ag} / \mathrm{AgCl}$ ) for seven days and operated in controlled temperature of $28{ }^{\circ} \mathrm{C}$. From the eighth day onwards, the anode poising was discontinued and the MFCs were connected to external resistors of $1,000 \Omega$.

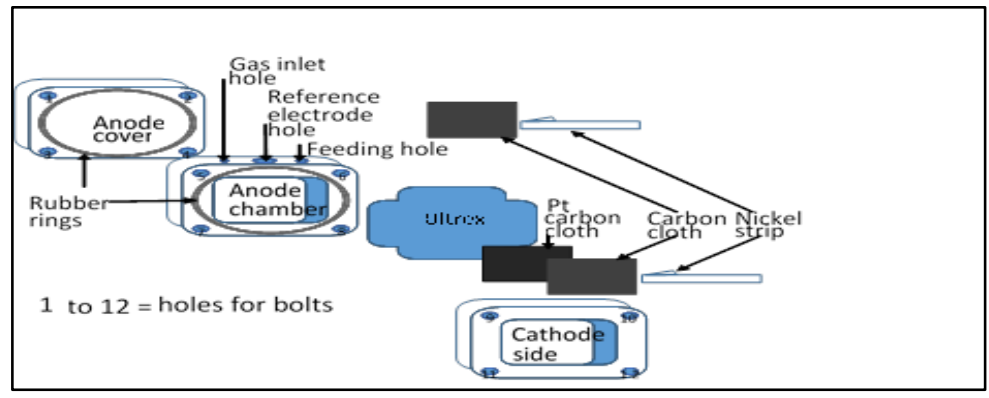

Figure 1. MFC used in this study

\section{Analytical methods and calculation}

Cell voltage $(E)$ across the external resistor and cell current generated from the anode fixed potential poised were measured every twice a day using a Digitech QM 1326 multimeter or every $30 \mathrm{~s}$ to 30 min using a four channel Quadstat 164 potentiostat (eDAQ Pty Ltd, NSW, Australia) and continuous recording using an e-corder 1621 (eDAQ Pty Ltd, NSW, Australia) data acquisition system. Current $(I)$ and power $(P)$ were calculated using the Ohm's law (Equation 1 and 2):

$$
\begin{aligned}
& I=\frac{E}{R e x t} \quad, I_{\text {density }}=\frac{I}{\text { Anode area }} \\
& P=I x E, P_{\text {density }}=\frac{P}{\text { Anode area }}
\end{aligned}
$$

where $E$ represents circuit's potential and $R_{\text {ext }}$ represents circuit external resistance, with the current density, $I_{\text {density }}$ and power density, $P_{\text {density }}$ normalized by the projected area of the anode [14].

Dissolved oxygen concentration in the anolyte was determined before the gas swapping activity from the aerobic MFCs as $7.5 \mathrm{ppm}$, using HQ40d portable multi-parameter meter ( $\mathrm{pH} /$ conductivity/ dissolved oxygen/ ORP/ ISE) 
(Hach Company, Colorado, US). The polarization curve and the power density curves were produced by using method in Luo et al. [14] and Watson and Logan, [15] to obtain the open circuit voltage (OCV), $P_{\max }, I_{\max }$ and $R_{\text {int }}$ of the system. In this study, the polarization curves were obtained using multiple resistors ( $820 \mathrm{k} \Omega$ to $18 \mathrm{k} \Omega$ ), with each resistance changed in decreasing order after every pseudo steady-state achieved or not more than $20 \mathrm{~min}$ intervals (which ever comes first) over a complete fed batch cycle. Analysis was conducted once the voltage output was stabilised after replenishing the media. The analysis was done for two consecutive cycles to ensure that the voltage response was unchanged with successive cycles.

\section{Results and Discussion}

Current density shows that once the anode poising was discontinued, only anaerobic MFCs show high current density with total daily average from day-8 till day- 25 of $38.26 \pm 0.13 \mathrm{~mA} / \mathrm{m}^{2}$ and lowest by aerobic MFCs of 2.08 $\pm 0.01 \mathrm{~mA} / \mathrm{m}^{2}$ while the control gave an average of $20.65 \pm 0.28 \mathrm{~mA} / \mathrm{m}^{2}$ (Figure 2). As soon as the MFC characterisation started (day 23, 24 and 25), the aerobic MFCs began to show significant in current density (t-test, $\mathrm{p}<0.05$ ), which is higher than anaerobic MFCs with total daily average from day-26 till day-30 of $70.93 \pm 0.19$ and $67.49 \pm 0.32 \mathrm{~mA} / \mathrm{m}^{2}$ respectively. For the control system, there was not much increase in current density recorded after day-26, $30.69 \pm 0.68 \mathrm{~mA} / \mathrm{m}^{2}$.

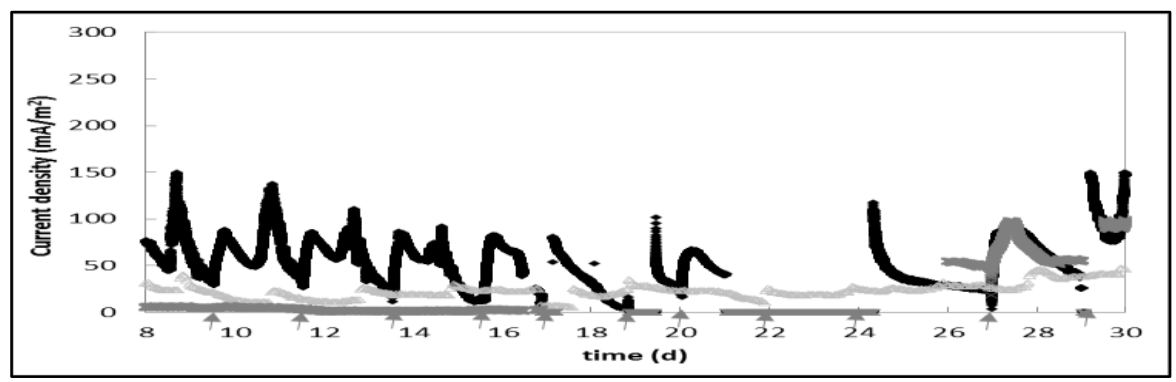

Figure 2. Biocatalytic current generation compared between aerobic and anaerobic environment. The air-cathode MFCs: anode chamber bubbled with nitrogen $(\checkmark)$, anode chamber bubbled with air (x) and control $(\triangle)$. The frequency of batch feeding mode was in daily average (represented by $\uparrow)(\mathrm{n}=2)$.

The poising of the anode was to allow consistent control of the biofilm electrode potential, by making the electrode as the sole electron acceptor [16]. The reason of nitrogen bubbling into the anode compartment was to accelerate the anaerobic condition in the system simultaneously increase the MFC electrochemical performance. The control MFCs were solely depending on the bacteria in the anode chamber to create anaerobic environment by gradually consuming the soluble oxygen in the anolyte [17]. The current density generated by the control MFCs was almost 2fold less than that generated by nitrogen bubbled MFCs. The high mass of bacteria inoculated in the anode compartment of the control MFCs, capable to consume oxygen available in the chamber for a short time. When the condition became suitable for anaerobic bacteria to survive and perform anodophilic transfer, then only current density started to gain pace. A similar situation was observed by Hutchinson et al. [18], who stated the importance of having the anode compartment free of diffused oxygen from the cathode esspecially during startup. In this study, feeding was done manually through a designated cavity at the top of the MFC reactor. This action might allow air to seep into the control MFCs, while for the anaerobic MFCs, the pressure created by the nitrogen bubbled MFC kept the air out during feeding. Therefore, the nitrogen bubbled MFCs could generate high current without the interference of air. In contrast, air bubbled MFCs remained at much lower current density than the control MFCs during the gassing period.

The characterisation of the MFCs for power and polarization curves, appeared to increase the current intensity of the aerobic and the anaerobic MFCs. From the Ohm's law in equation 1, new voltage at the electrodes can be obtained through changing the $R_{e x t}$. During the characterisation analysis, the $R_{e x t}$ applied had values larger than the fixed $R_{e x t}$ used for the MFCs' operation. The large $R_{e x t}$ values were necessary to obtain the standard MFC characterisation and 
polarization curves. This might attributed to the moment surged in current intensity once the MFC characterisation was stopped and the system were again connected to the fixed $R_{\text {ext }}$, which had much lower value. Similar incident was experienced by Aelterman et al. [19], in their studies on the effect of $R_{e x t}$ ranges towards MFCs current generation. They found that the current intensity of their MFCs increased by 3.29 -fold when they changed the $R_{e x t}$ from 50 to $10.5 \Omega$. However, further study is necessary to identify reason on how the aerobic increased in current density by one fold more than the anaerobic after characterisation analysis was done.

The switching of gasses between air and nitrogen began on day-33 until day 44 . The total daily average current calculated for the 11 days after gas swapping did not show any significant in current density (t-test, $\mathrm{p}>0.05)$ between before (day-26 to 30) and after gas swapping for each MFC conditions (day-33 to 44): $49.89 \pm 0.19 \mathrm{~mA} /$ $\mathrm{m}^{2}$ (nitrogen gassed MFCs) and $74.81 \pm 0.18 \mathrm{~mA} / \mathrm{m}^{2}$ (aerated MFCs) (Figure 3).

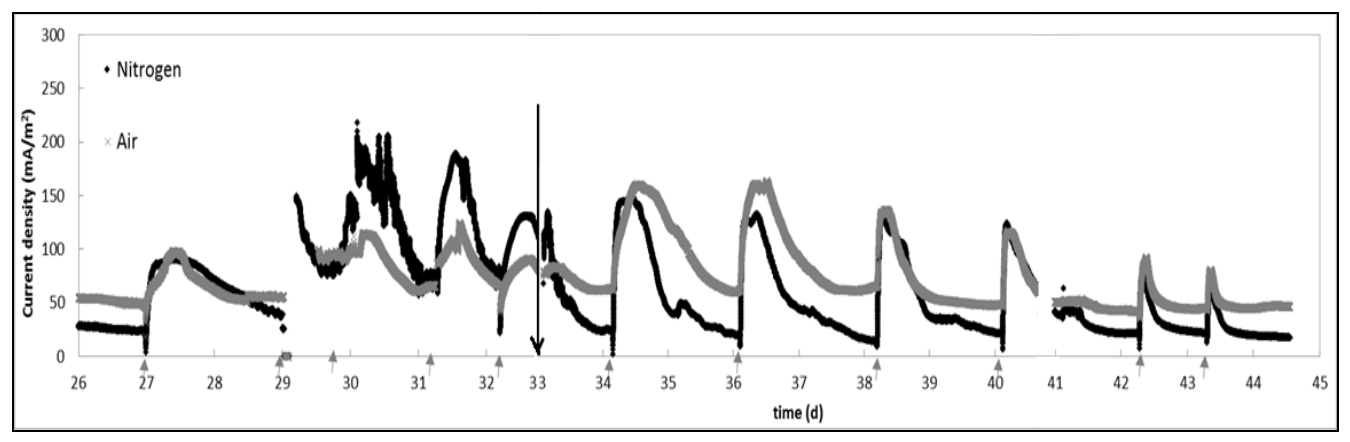

Figure 3. Effect of gas swapping ( $\downarrow$ ) between the aerobic and anaerobic MFCs. The frequency of batch feeding mode was in average every two days (represented by $\uparrow)(n=2)$

However, when looking at the individual daily average in current density (Table 1), there seems to be clear decreasing trend for the anaerobic MFCs from the beginning of the swapping till day-43. For aerobic MFCs, the effect of nitrogen bubble seems evidenced within the first four days after gas swapping and the anaerobic effect slowly became reduced and stabilized at about $50 \mathrm{~mA} / \mathrm{m}^{2}$. Further study would need to be carried out to understand this phenomenon.

The impact of the gas swapping before and after can be observed through the polarization and the power curves. Comparisons done on the OCV from the polarization curves between the aerobic and anaerobic MFCs before and after the gas swapping (Figure 4a), which was about 20 days apart and the control, shows that the aerobic MFCs possessed 2.3 fold higher OCV than before the gas swapping $(150 \mathrm{mV}$, vs. $\mathrm{Ag} / \mathrm{AgCl})$, and 1.2 fold higher $\mathrm{OCV}$ than both the anaerobic (before and after gas swapping) and the control MFCs (300 mV, vs. $\mathrm{Ag} / \mathrm{AgCl}$ )(Figure 4a). The OCV zone is known as the activation loss zone and refers to the electron transfers reaction at the electrode surface. The OCV is the highest voltage produced in an MFC, measured in the absence of current and take into consideration various potential losses as follows (Equation 3 and 4)[20, 21].

$$
\begin{aligned}
& O C V=E_{\text {cell }}+I R_{\text {int }} \\
& E_{\text {cell }}=E_{\text {emf }}-\left(\sum \eta_{a}+\left|\sum \eta_{c}\right|+I R_{\Omega}\right)
\end{aligned}
$$

where the $E_{\text {cell }}$ is the measured cell voltage, $I R_{\text {int }}$ is the sum of all internal losses of the MFC, $\sum \eta_{a}$ and $\left|\sum \eta_{c}\right|$ represents the overpotentials of the anode and cathode respectively. The overpotential of the anode and cathode reflect the influence of slow kinetics of heterogenous electron transfer, which is the movement of electrons between a chemical species and a solid-state electrode, together with ohmic resistance and concentration 
gradients [22]. $E_{\text {emf }}$ is the cell electromotive force from the differece of cathode potential, $E_{c a t}$ to anode potential, $E_{a n}$, and $I R_{\Omega}$ represents the sum of all ohmic losses.

Table 1. Daily average current calculated after gas swapping ( \pm standard error of mean) $(n=2)$

\begin{tabular}{lcc}
\hline Day & $\begin{array}{c}\text { Anaerobic MFCs bubbled } \\
\text { with air }\left(\mathbf{m A} / \mathbf{~ m}^{2}\right)\end{array}$ & $\begin{array}{c}\text { Aerobic MFCs bubbled } \\
\text { with nitrogen }\left(\mathbf{m A} / \mathbf{~ m}^{2}\right)\end{array}$ \\
\hline $26-30_{\text {(before gas swap) }}$ & $70.93 \pm 0.19$ & $67.49 \pm 0.32$ \\
Gas swapping dates: & & \\
$33-34$ & $53.40 \pm 0.58$ & $71.92 \pm 0.16$ \\
$35-36$ & $33.89 \pm 0.17$ & $85.28 \pm 0.39$ \\
$36_{\text {(feed) }}-37$ & $82.84 \pm 0.69$ & $124.66 \pm 0.59$ \\
$37_{-38}$ & $30.68 \pm 0.17$ & $69.21 \pm 0.17$ \\
$38_{\text {(feed) }}-39$ & $74.19 \pm 0.75$ & $87.11 \pm 0.53$ \\
$39_{-40}$ & $30.70 \pm 0.08$ & $50.43 \pm 0.04$ \\
$40_{\text {(feed) }}-41$ & $69.36 \pm 0.54$ & $72.69 \pm 0.44$ \\
$41_{\text {(feed) }}-42$ & $31.66 \pm 0.16$ & $47.88 \pm 0.07$ \\
$42_{\text {(feed) }}-43$ & $33.08 \pm 0.29$ & $52.23 \pm 0.25$ \\
$43_{\text {(feed) }}-44$ & $28.49 \pm 0.23$ & $49.15 \pm 0.17$ \\
\hline
\end{tabular}
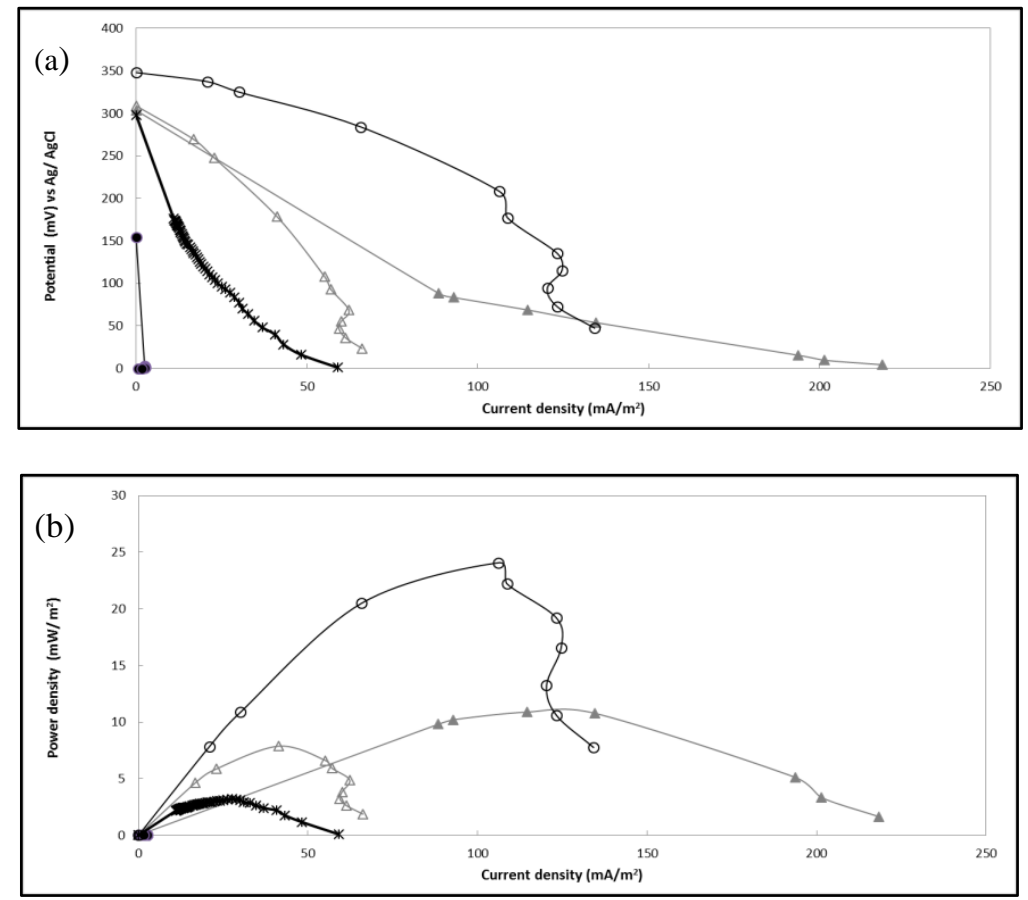

Figure 4. Polarization (a) and power density (b) curves recorded. Symbols in the figure represent anaerobic MFCs before $(\triangle)$ and after $(\triangle)$ gas switching and aerobic MFCs before $(\mathbf{O})$ and after $(\mathbf{O})$ gas switching as well as controls $(\mathrm{x})(\mathrm{n}=2)$. 
Hence, apart from the low concentraiton of oxygen in air (ca. 21\%), the reduced in OCV could be attributed to factors, such as potential generated by the exoelectrogen that formed the anodic biofilm, diffused oxygen into the anode compartment that interrupts the anodic biofilm and inefficient oxygen reduction reaction (ORR) occurs at the cathode site [23]. Ideally, an OCV of an air-cathode MFC should be around $+621 \mathrm{mV}$ (vs. Ag/AgCl) $(+820 \mathrm{mV}$, vs. SHE) when pure oxygen is used. The $820 \mathrm{mV}$ is based on the potential of redox couple between pure oxygen and water $\left(1 / 2 \mathrm{O} 2 / \mathrm{H}_{2} \mathrm{O}, 2 \mathrm{e}^{-}\right)$[24]. However when air is used at the cathode side, OCV obtained are much lower than the ideal. In an MFC study done by $\mathrm{Li}$ et al. [25] using anaerobic wastewater as inoculum in a $75.6 \mathrm{~mL}$ dual chambered MFC with air bubbled in deionized catholyte, OCV was within the range of +419 to $+489 \mathrm{mV}$ (vs. $\mathrm{Ag} / \mathrm{AgCl}$ ). $\mathrm{In}$ other study done by Khan et al. [26] using anaerobic digester from palm oil waste as inoculum in $20 \mathrm{~mL}$ single chamber air-cathode, found that the OCV also dependent on the catalyst applied onto the cathode, which could ranged from +385 to $+626 \mathrm{mV}$ (vs. $\mathrm{Ag} / \mathrm{ACl}$ ). In this study, however, the high OCV recorded for the aerobic MFCs after the anolyte was continously bubbled with nitrogen for 11 days, might have increased the population of the exoelectrogens in the anode compartment, thus reduce the overpotential of the anode and the internal losses in the MFC.

From the MFC characterisations (Table 2), positive changed were seen on the aerobic MFCs where the $P_{\max }$ increased by more than 1,000- fold, increased in $I_{\max }$ by 42 -fold, once the air in the anolyte was replaced with nitrogen. The change in the anaerobic MFCs after the nitrogen bubble replaced with air was small, about 1.4- fold of decreased in $P_{\max }$ along with a slight decreased in $I_{\max }$ by 2.8 -fold. This increase in both $I_{\max }$ and $P_{\max }$ for the aerobic MFCs after the gas swapping shows that when MFCs were in the aerobic state, the exoelectrogens were already there, and these became active once the environment turned to anaerobic. Exoelectrogens are believed to be facultative bacteria that could survive in both conditions, aerobic and anaerobic [27]. In the air bubbling anode chamber, the small number of exoelectrogenic bacteria near the anode still survive because concentration of oxygen lessen with the increasing depth of biofilm; while the centre is already anaerobic [28]. Diffused oxygen is consumed in the outer layers of biofilm, providing favourable conditions for growth of facultative and strict anaerobes in the deep layers of the biofilm [29]. Similar to oxygen, substrate diffusion also decrease with the increase of biofilm mass depth from bulk fluid to the interior biofilm [30].

Table 2. Details obtained from MFC electrochemical characterizations

\begin{tabular}{lccc}
\hline MFC & $\begin{array}{c}\boldsymbol{P}_{\max } \\
\left(\mathbf{m W} / \mathbf{m}^{\mathbf{2}}\right)\end{array}$ & $\begin{array}{c}\boldsymbol{I}_{\max } \\
\left(\mathbf{m A} / \mathbf{m}^{\mathbf{2}}\right)\end{array}$ & $\begin{array}{c}\boldsymbol{R}_{\text {int }} \\
(\mathbf{k} \boldsymbol{\Omega})\end{array}$ \\
\hline Anaerobic- before gas swap & $10.88 \pm 8.33$ & $114.61 \pm 49.97$ & $30.55 \pm 0.00$ \\
Anaerobic- after gas swap (arobic condition) & $7.87 \pm 2.13$ & $41.29 \pm 5.35$ & $226.40 \pm 2.45$ \\
Aerobic- before gas swap & $0.02 \pm 0.02$ & $2.50 \pm 2.25$ & $50.92 \pm 0.00$ \\
Aerobic- after gas swap (anaerobic condition) & $24.07 \pm 4.06$ & $106.22 \pm 11.20$ & $107.79 \pm 3.89$ \\
Control & $2.91 \pm 2.52$ & $31.09 \pm 17.94$ & $2.41 \pm 0.00$ \\
\hline
\end{tabular}

Although both the $P_{\max }$ and the $I_{\max }$ showed expected results with the swapping of gasses, the $R_{\text {int }}$ for aerobic MFCs showed an increment of 2.1-fold after the gas swapping. Comparison between the $R_{\text {int }}$ of aerobic and anaerobic MFCs after the gas swapping however shows that the nitrogen replacing the air in aerobic MFCs, reduced its $R_{\text {int }}$ lower than that of anaerobic MFCs. This effect can be seen clearly in the power curves where the curve of aerobic MFCs after the swapping was not symmetrical as the power curve of the anaerobic MFCs (Figure 4b). Based on Logan et al. [20], the symmetric nature of the power density curve obtained from the MFC characterisation analysis, which was also seen in this study represents a high $R_{\text {int }}$ in an MFC mostly due to the ohmic resistance $\left(R_{\Omega}\right)$ at the point of $P_{\max } . R_{\Omega}$ is derived from any material that creates resistance in the system, such as substrates, bacteria, gap between electrodes, loose contacts between components, and low ionic conductivity in the substrate. The continuous air bubbling in the anode chamber probably helped with the growth of aerobic microbes due to a direct reduction of 
oxygen in the cell to increase biomass production. Although increase in biomass means increase in the NADH production, which leads to increase in electrons production, most of these electrons however will be consumed for biomass before able to generate electricity [3]. This could be the reason for the high $R_{\text {int }}$ observed from aerobic MFCs before the gas swapping with very poor $I_{\max }$ and $P_{\max }$ [24].

Although this study was able to culture exoelectrogen from aerobic sludge originated from trickling filter, the electrochemical performance was way too low from results that have been reported in other publications, which is no less than $100 \mathrm{~mW} / \mathrm{m}^{2}$. According to Rahimnejad et al. and Haslett et al [31, 32], the performance of MFCs are commmonly associated with the following: 1) Substrates oxidation in the anode compartment, 2) Microorganism used for inoculum, 3) Mediator, 4) Permeabililty of cation exchange membrane (if any), 5) Electrode material and their surface area, 6) Electron acceptor at the cathode chamber, 7) Electron trasport pathway to anode surface, 8) Overpotential at the electrodes, 9) External load applied, 10) Distance between electrodes, 11) Mass transport, and 12) Operational temperature [31, 32]. For instance Feng et al. [33] analysed the effect of acid modified carbon fiber brush in $28 \mathrm{~mL}$ air-cathode MFC having $20 \%$ inoculum from domestic wastewater with external load of $1 \mathrm{k} \Omega$, achieved $P_{\max }$ of $1,370 \mathrm{~mW} / \mathrm{m}^{2}$. Watson and Logan [15] adapted similar MFC design with an increased of inoculum concentration upto 50\%, different type of microorganism and used a non modified carbon fiber brush, had achieved 1.6 fold lower $P_{\max }$ than the later. Santoro et al. [34] on the other hand with completely different MFC design, used 4.6 fold more volume and non modified carbon cloth for anode and cathode, only achieved 268 $\mathrm{mW} / \mathrm{m}^{2}$ of $P_{\max }$. To identify the reason of poor electrochemical performance in this study and to reduce such high $R_{\text {int }}$, the variables affecting the performance of MFCs listed above need to be analyzed and compare them with those having similar MFC designs.

\section{Conclusion}

The goal of this study was to analyse the effect of long-duration exposure towards oxygen in air through gas swapping on the electrochemical performance of enriched multi-cultured bacteria in air-cathode MFCs. The results showed that prolong exposure in $7.5 \mathrm{mg} / \mathrm{L}(\mathrm{ppm})$ of dissolved oxygen MFCs for a month on the enriched multicultured bacteria culture, makes the bacteria electrochemically inactive and produced low power and current generation. This however is not permanent since it could easily and quickly be rectified with improvements up to $100 \%$ in $P_{\max }$ and $I_{\max }$ and a reduction in $R_{\text {int }}$ of up to $53 \%$, when introduced into an anaerobic environment. Future studies could be carried out to gain a more in-depth understanding on electrochemical performance of MFCs before and after gas swapping, and also understanding of its effect on microbial community in the biofilm and half-wave redox potential $\left(E_{1 / 2}\right)$. Further research can also be carried out on electrode polarization and the effect of different oxygen concentration ranges on MFC performance.

\section{Acknowledgement}

This work was supported by funding from Ministry of Higher Education of Malaysia (MoHE), Universiti Kebangsaan Malaysia (UKM), Lincoln University, Canterbury, New Zealand and lab facility from Lincoln Agritech Ltd, Christchurch, New Zealand.

\section{References}

1. Rittmann, B. E. (2006). Microbial ecology to manage processes in environmental biotechnology. Trends in Biotechnology, 24(6): 261 - 266.

2. Kim, H. J., Park, H. S., Hyun, M. S., Chang, I. S., Kim, M. and Kim, B. H. (2002). A mediator-less microbial fuel cell using a metal reducing bacterium, Shewanella putrefaciens. Enzyme and Microbial Technology, 30(2): $145-152$.

3. Li, S.-L., Freguia, S., Liu, S. M., Cheng, S. S., Tsujimura, S., Shirai, O. and Kano, K. (2010). Effects of oxygen on Shewanella decolorationis NTOU1 electron transfer to carbon-felt electrodes. Biosensors and Bioelectronics, 25: 2651 - 2656.

4. Wang, Y.-F., Cheng, S. S., Tsujimura, S., Ikeda, T. and Kano, K. (2006). E. coli-catalyzed bioelectrochemical oxidation of acetate in the presence of mediators. Bioelectrochemistry, 69(1): 74 - 81.

5. Liu, H., Cheng, S. and Logan, B. E. (2005). Production of electricity from acetate or butyrate using a singlechamber microbial fuel cell. Environmental Science \& Technology, 39(2): 658 - 662. 
6. Kim, B. H., Park, H. S., Kim, H. J., Kim, G. T., Chang, I. S., Lee, J. and Phung, N. T. (2004). Enrichment of microbial community generating electricity using a fuel-cell-type electrochemical cell. Applied Microbiol Biotechnology, 63(3): $672-681$.

7. Kim, B., Ikeda, T., Park, H. S., Kim, H. J., Hyun, M. S., Kano, K., Takagi, K. and Tatsumi, H. (1999). Electrochemical activity of an Fe(III)-reducing bacterium, Shewanella putrefaciens IR-1, in the presence of alternative electron acceptors. Biotechnology Techniques, 13(7): 475 - 478.

8. Biffinger, J. C., Byrd, J. N., Dudley, B. L. and Ringeisen, B. R. (2008). Oxygen exposure promotes fuel diversity for Shewanella oneidensis microbial fuel cells. Biosensors and Bioelectronics, 23(6): 820 - 826.

9. Mohan, S. V., Velvizhi, G., Modestra, J. A., and Srikanth, S. (2014). Microbial fuel cell: Critical factors regulating bio-catalyzed electrochemical process and recent advancements. Renewable and Sustainable Energy Reviews, 40: 779 - 797.

10. Kim, J. R., Min, B. and Logan, B. E. (2005). Evaluation of procedures to acclimate a microbial fuel cell for electricity production. Applied Microbial Biotechnology, 68: 23 - 30.

11. Rader, G.K. and Logan, B. E. (2010). Multi-electrode continuous flow microbial electrolysis cell for biogas production from acetate. International Journal of Hydrogen Energy, 35(17): 8848 - 8854.

12. Atlas, R. M. (2005). Handbook of microbiological media. Second Edition ed. Acetate agar, Fluorida: Taylor \& Francis Group.

13. Weld, R. J. and Singh, R. (2011). Functional stability of a hybrid anaerobic digester/microbial fuel cell system treating municipal wastewater. Bioresource Technology, 102(2): 842 - 847.

14. Luo, Y., Zhang, F., Wei, B., Liu, G., Zhang, R. and Logan, B. E. (2011). Power generation using carbon mesh cathodes with different diffusion layers in microbial fuel cells. Journal of Power Sources, 196(22): 9317 9321.

15. Watson, V.J. and Logan, B. E. (2011). Analysis of polarization methods for elimination of power overshoot in microbial fuel cells. Electrochemistry Communications, 13(1): p. 54-56.

16. Babauta, J., Renslow, R., Lewandowski, Z. and Beyenal, H. (2012). Electrochemically active biofilms: facts and fiction. A review. Biofouling, 28(8): 789 - 812.

17. Ringeisen, B. R., Ray, R. and Little, B. (2007). A miniature microbial fuel cell operating with an aerobic anode chamber. Journal of Power Sources, 165: 591 - 597.

18. Hutchinson, A. J., Tokash, J. C. and Logan, B. E. (2011). Analysis of carbon fiber brush loading in anodes on startup and performance of microbial fuel cells. Journal of Power Sources, 196(22): 9213 -9219.

19. Aelterman, P., Versichele, M., Marzorati, M., Boon, N. and Verstraete, W. (2008). Loading rate and external resistance control the electricity generation of microbial fuel cells with different three-dimensional anodes. Bioresource Technology, 99: 8895- 8902.

20. Logan, B. E., Hamelers, B., Rozendal, R., Schröder, U., Keller, J., Freguia, S., Aelterman, P., Verstraete. W. and Rabaey, K. (2006). Microbial fuel cells: Methodology and technology. Environmental Science \& Technology, 40(17): 5181 - 5192.

21. Osman, M. H., Shah, A. A. and Walsh, F. C. (2010). Recent progress and continuing challenges in bio-fuel cells. Part II: Microbial. Biosensors and Bioelectronics, 26(3): 953 - 963.

22. Tayhas, G., Palmore, R. and Whitesides, M. G. (1994). Chapter 14: Microbial and enzymatic biofuel cells, in Enzymatic conversion of biomass for fuels production. American Chemical Society: Massachusetts.

23. Cheng, S., Liu, H. and Logan, B. E. (2006). Increased power generation in a continuous flow MFC with advective flow through the porous anode and reduced electrode spacing. Environmental Science \& Technology, 40(7): $2426-2432$.

24. Logan, B. E. (2008). Mechanism of electron transfer, in Microbial Fuel Cell. John Wiley \& Sons, Inc: New Jersey. pp. 13.

25. Li, X.M., Cheng, K. Y., Selvam, A. and Wong, J. W (2013). Bioelectricity production from acidic food waste leachate using microbial fuel cells: Effect of microbial inocula. Process Biochemistry, 48(2): 283 - 288.

26. Khan, M.R., Chan, K. M., Ong, H. R., Cheng, C. K. and Rahman, W. (2015). Nanostructured pt/mno2 catalysts and their performance for oxygen reduction reaction in air cathode microbial fuel cell. International Journal of Electrical, Computer, Electronics and Communication Engineering, 9(3): 295 - 301.

27. Lefebvre, O., Shen, Y., Tan, Z., Uzabiaga, A., Chang, I. S. and Ng, H. Y. (2011). A comparison of membranes and enrichment strategies for microbial fuel cells. Bioresource Technology, 102(10): 6291 - 6294. 
28. Cunningham, A.B., Lennox, J. E. and Ross, R. J. (2014). The Biofilms Hypertextbook: Intermediate level. Chapter 2: Biofilm formation and growth 2001-2008; Section 3: Biofilm development]. Available from: http://biofilmbook.hypertextbookshop.com/public_version/contents/chapters/chapter002/ section003/blue/page003.html [Access online 19 September 2014].

29. Pastorella, G., Gazzola, G., Guadarrama, S. and Marsili, E. (2012). Biofilms: Applications in bioremediation, in Microbial Biofilms: Current research and applications, G. Lear and G.D. Lewis, Editors, Horizon Scientific Press: UK. : 73 - 98.

30. Dirckx, P. (1997). Biofilm structure with labels, Biofilm.jpg, Center for Biofilm Engineering: Montana.

31. Rahimnejad, M., Ghoreyshi, A. A., Najafpour, G. and Jafary, T. (2011). Power generation from organic substrate in batch and continuous flow microbial fuel cell operations. Applied Energy, 88(11): 3999 -4004.

32. Haslett, N. D. (2012). Development of a eukaryotic microbial fuel cell using Arxula adeninivorans, in Department of Agricultural Sciences. Lincoln University. pp. 245.

33. Feng, Y., Yang, Q., Wang, X. and Logan, B. E. (2010).Treatment of carbon fiber brush anodes for improving power generation in air-cathode microbial fuel cells. Journal of Power Sources, 195(7): 1841 - 1844.

34. Santoro, C. Lei, Y., Li, B. and Cristiani, P. (2012). Power generation from wastewater using single chamber microbial fuel cells (MFCs) with platinum-free cathodes and pre-colonized anodes. Biochemical Engineering Journal, 62: 8 - 16 . 